\title{
Induction of Thrombospondin 1 by Retinoic Acid Is Important during Differentiation of Neuroblastoma Cells
}

\author{
Valerie P. Castle, * Xianglan Ou, * Susan O'Shea, ${ }^{\star}$ and Vishva M. Dixit* \\ Departments of ${ }^{*}$ Pediatrics, ${ }^{\ddagger}$ Anatomy and Cell Biology, and ${ }^{\S}$ Pathology, \\ University of Michigan Medical School, Ann Arbor, Michigan 48109
}

\begin{abstract}
Neuroblastoma, a malignant neoplasm that arises in the adrenal medulla or sympathetic ganglion, is one of the most common solid tumors of childhood. Reports that neuroblastomas spontaneously mature to form benign ganglioneuromas have prompted investigations into the efficacy of using agents that induce neuronal differentiation in the treatment of this malignancy. Retinoic acid is one agent in particular that has been shown to induce growth inhibition and terminal differentiation of neuroblastoma cell lines in vitro. Using the human neuroblastoma cell line SMH-KCNR, we have investigated the role of the extracellular matrix protein thrombospondin in retinoic acid induced neuroblastoma differentiation. Treatment with retinoic acid results in a rapid induction (within $4 \mathrm{~h}$ ) of thrombospondin (TSP) message which is independent of intervening protein synthesis and superinducible in the presence of cycloheximide. This suggests that TSP functions as a retinoic acid inducible immediate early response gene. A concomitant increase in both cell associated and soluble forms of TSP protein can be detected within 24 h of retinoic acid treatment. A functional role for TSP in SMH-KCNR differentiation was established in experiments which showed that exposure to anti-TSP monoclonal antibodies delay retinoic acid differentiation for $\mathbf{4 8}$ h. At the time the cells overcome the effects of TSP inhibition, laminin production becomes maximal. Treatment of the cells with a combination of anti-TSP and antilaminin antibodies results in complete inhibition of differentiation. (J. Clin. Invest. 1992. 90:1857-1863.) Key words: biological sciences • molecular biology • cellular differentiation • extracellular matrix • neoplastic processes
\end{abstract}

\section{Introduction}

Neuroblastoma accounts for $10 \%$ of all cancers of childhood and remains one of the most common solid tumors in children. Arising in the adrenal medulla or sympathetic ganglia, this tumor has been known to spontaneously mature to benign ganglioneuromas (1). Given the favorable outcome associated with spontaneous differentiation, agents that induce neuronal differentiation are being investigated for their therapeutic value

Address correspondence to Dr. Valerie P. Castle, The University of Michigan Medical School, Department of Pediatrics, MSRB1 A510D, Box 0634, Ann Arbor, MI 48109.

Received for publication 4 March 1992 and in revised form 2 June 1992.

J. Clin. Invest.

(C) The American Society for Clinical Investigation, Inc.

$0021-9738 / 92 / 11 / 1857 / 07 \$ 2.00$

Volume 90, November 1992, 1857-1863 in the treatment of neuroblastoma. Retinoic acid (RA) ${ }^{1}$ is one agent which is capable of inducing differentiation of neuroblastoma cell lines in vitro (2). Retinoic acid is also capable. of initiating epithelial differentiation $(3,4)$, embryonal carcinoma differentiation ( 5 ), and it is required for vertebrate development (6-8). Acting through nuclear receptors, RA induces the expression of many gene products, including homeobox genes and components of the extracellular matrix, including laminin (9). The induction of these proteins and especially laminin is thought to be important in neural differentiation, since laminin, in conjunction with other matrix proteins, is a potent stimulator of neurite outgrowth (10). This induction, however, occurs as a secondary response dependent on intervening protein synthesis (11).

Thrombospondin (TSP) is another component of the extracellular matrix which has been implicated in neuronal differentiation. TSP is a large trimeric glycoprotein $\left(M_{\mathrm{r}} 420,000\right.$ D) with functional domains capable of binding collagen, calcium, heparin, and cell surface receptors $(12,13)$. Recently, two homologous forms of TSP (TSP 1 and TSP 2) that are encoded by related but distinct genes (14) have been identified. The observations that have identified an important role for TSP in neuronal differentiation include the finding that during murine embryogenesis TSP 1 and 2 localize to developing neural tissue as evidenced by deposition along developing fiber tracts, pathways of cell migration such as neural crest migration, and regions of axonal outgrowth (15, and unpublished observations). Secondly, when TSP 1 is immobilized on tissue culture plastic, it has been shown to support neurite outgrowth from primary cultures of central and peripheral mouse neurons and from the rat pheochromocytoma cell line, PC $12(16,17)$. Given that immobilized TSP is capable of inducing neurite outgrowth from primary neuronal cultures and PC 12 cells, it was logical to ask whether induction of TSP was part of the neuronal differentiation program which resulted in neurite outgrowth. Such a question is best addressed using an inducible neuronal differentiation system, so that it is possible to monitor both TSP synthesis and neurite outgrowth. In addition, such a system is quantifiable and susceptible to antibody perturbation experiments, which in turn allow for an accurate assessment of the role of the factor under study. A variety of inducible cell lines are available to investigate this question. We have chosen to examine the induction and role of TSP during neuronal differentiation of a human neuroblastoma cell line in response to retinoic acid. A major reason for this choice was that retinoic acid is being used therapeutically in the treatment of neuroblastomas, and it is thus imperative that the mechanism by which it influences neuronal cell differentiation

1. Abbreviations used in this paper: RA, retinoic acid; TSP, thrombospondin. 
be elucidated. In addition, retinoids can also act as teratogens, inducing malformation of the central nervous system, cleft palate, and craniofacial abnormalities, sites where TSP is highly expressed during development (15).

\section{Methods}

Cell culture and retinoic acid treatment. The SMH-KCNR cell line, passage seven (gift of C. P. Reynolds, Children's Hospital, Los Angeles, CA ) was used for all experiments (18). Cells were grown in RPMI 1640 supplemented with $10 \%$ fetal bovine serum and $10 \mathrm{mM}$ glutamine, and incubated at $37^{\circ} \mathrm{C}$ with $5 \% \mathrm{CO}_{2}$. Cells were treated for various time periods with all-trans retinoic acid (Sigma Chemical Co., St. Louis, MO) dissolved in $100 \%$ ethanol at a final concentration of $5 \mu \mathrm{M}$. Cycloheximide (Sigma Chemical Co.) was used where indicated at a final concentration of $10 \mu \mathrm{g} / \mathrm{ml}$ and applied $30 \mathrm{~min}$ before RA treatment. Controls for the retinoic acid induction were ethanol-only-treated cells grown under the same conditions. For monoclonal antibody inhibition studies, cells were grown in RPMI in the absence of serum to remove any exogenous source of TSP and the media was supplemented with insulin, transferrin, selenium, BSA, and linoleic acid (ITS+);(Collaborative Research, Inc., Bedford, MA).

RNA and Northern analysis. $5 \times 10^{6}$ cells from each treatment condition were harvested by lysis with $6 \mathrm{M}$ guanidine- $\mathrm{HCl}$ and RNA prepared as described previously (19). $10 \mu \mathrm{g}$ of RNA from each sample was electrophoresed on a $1 \%$ agarose gel. Equivalent loading and integrity of each preparation were evaluated by ethidium-bromide staining of the $28 \mathrm{~S}$ rRNA bands. After electrophoresis, RNA was transferred to nitrocellulose and hybridized under conditions of high stringency ( 2 $X$ standard saline citrate $/ 1 \%$ SDS ) to ${ }^{32} \mathrm{P}$-labeled fragments of human cDNA specific for TSP 1 (20) or TSP 2 (gift of P. Byers, University of Washington, Seattle, WA). The TSP 1 specific probe corresponded to nucleotides 151-890, which encode the heparin binding domain of TSP 1. The TSP 2-specific probe was a 746-bp segment from the 3' untranslated region of human TSP 2.

Metabolic labeling and quantitative immunoprecipitations. Cells were treated with indicated concentrations of retinoic acid or ethanol (carrier) as described. $6 \mathrm{~h}$ before harvesting, the cells were placed into methionine- and cysteine-free RPMI supplemented with $1 \%$ BSA and $100 \mu \mathrm{Ci} / \mathrm{ml}$ of $\left[{ }^{35} \mathrm{~S}\right]$ methionine and $\left[{ }^{35} \mathrm{~S}\right]$ cysteine (trans-label; ICN Radiochemicals, Inc., Div. ICN Biomedicals, Inc., Irvine, CA). An equivalent number of TCA precipitable counts were incubated with rabbit anti-human TSP antibody (21) or rabbit anti-human laminin antibody (Telios Pharmaceuticals, Inc., San Diego, CA) at $4^{\circ} \mathrm{C}$ in the presence of protease inhibitors ( $1 \mu \mathrm{g} / \mathrm{ml}$ leupeptin, $1 \mu \mathrm{g} / \mathrm{ml}$ aprotinin, $10 \mu \mathrm{g} / \mathrm{ml}$ soybean trypsin inhibitor, and $1 \mu \mathrm{g} / \mathrm{ml}$ pepstatin ) and detergent containing buffer $\left(15 \mathrm{mM} \mathrm{NaCl}, 10 \mathrm{mM} \mathrm{NaH} \mathrm{PO}_{4}, 1 \%\right.$ Triton
$\mathrm{X}-100,0.5 \%$ deoxycholic acid, $0.1 \%$ SDS, and $20 \mathrm{mM}$ EDTA ). Immune complexes were precipitated with protein A-Sepharose beads and resolved on a $7.5 \%$ SDS polyacrylamide gel under reducing conditions as described previously (22).

Monoclonal antibody inhibition assays. Purified mouse monoclonal antibody, A 4.1, which recognizes the limited tryptic core region of human TSP 1 (23), was used to study the effect of TSP in retinoic acid induced differentiation. A second monoclonal antibody specific for the neurite promoting activity of laminin, designated as A 004 (24), was used in conjunction with A 4.1 in certain experiments as described. An irrelevant mouse monoclonal antibody M45Q (25) directed against an antigen expressed on breast milk macrophages was used as a negative control. A 4.1 was used at a final concentration of $50 \mu \mathrm{g} / \mathrm{ml}$. The anti-laminin antibody A 004 was supplied as ascites and used at a 1:100 dilution. Control antibody M45Q was used at a final concentration of $50 \mu \mathrm{g} / \mathrm{ml}$. Experiments were performed in duplicate and cells were photographed using an inverted microscope (E. Leitz, Inc., Rockleigh, $\mathrm{NJ}$ ) with a 35-mm camera. Neurite outgrowth was quantitated from photomicrographs using a digitizing tablet interfaced with a microcomputer. Distance from the edge of the cell to the neurite leading edge was determined in 20 cells from each treatment group in duplicate experiments and mean neurite length was compared between treatment groups using a two-tailed $t$ test. Additionally, incidence of neurite outgrowth was assessed from 50 cells from each treatment group. Neurites were scored as present if they were at least twice the length of the cell body.

Competitive inhibition studies. Competitive inhibition studies were performed to determine whether the $\mathrm{NH}_{2}$-terminal heparin binding domain or the RGD sequence in the carboxy-terminal domain of TSP were contributing to neurite outgrowth. For these studies, cells were treated with retinoic acid or ethanol ( carrier) in combination with heparin at three concentrations, $(10,100$, or $500 \mu \mathrm{g} / \mathrm{ml})$; or an RGD peptide (GRGDS; Telios Pharmaceuticals, Inc.) at two concentrations ( 100 or $500 \mu \mathrm{g} / \mathrm{ml}$ ).

\section{Results}

The expression of TSP during retinoic acid-induced neuroblastoma differentiation was investigated using the SMH-KCNR cell line, which extends neurites within $24 \mathrm{~h}$ of exposure to retinoic acid. RNA was isolated from these cells after treatment with retinoic acid or ethanol (carrier) and used for Northern blot analysis. As shown in Fig. 1, the expression of TSP 1 transcript is rapidly increased over basal levels within $4 \mathrm{~h}$ of retinoic acid treatment and is maximally expressed at $24 \mathrm{~h}$. TSP 1 expression then declines, but still remains detectable even after 4 d of treatment. Additionally, treatment of the cells with reti-

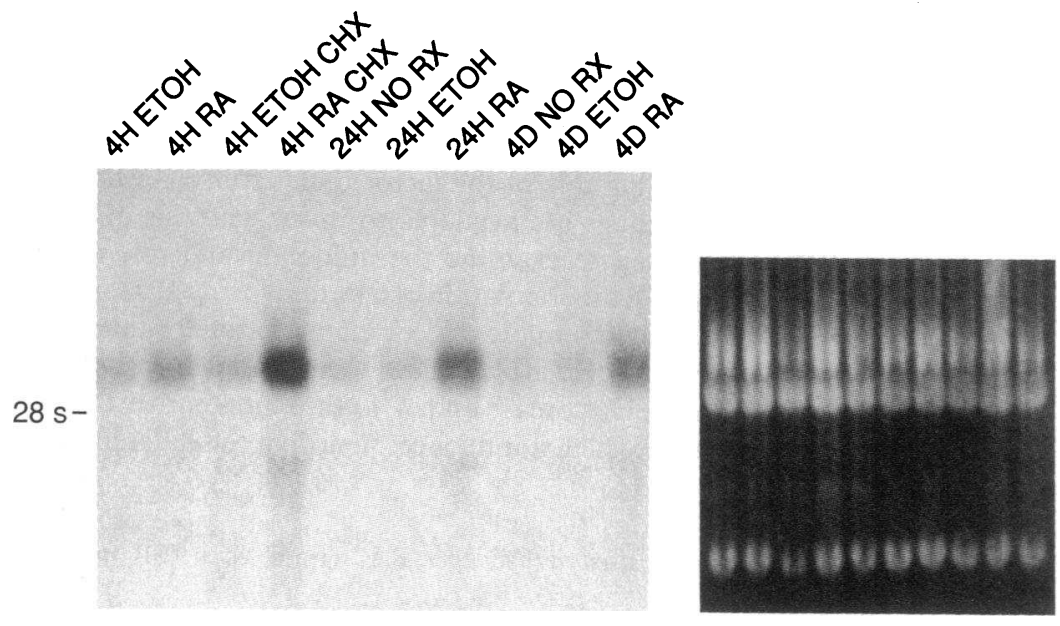

Figure 1. Northern blot analysis. RNA from SMHKCNR cells after treatment with control solvent $(E T O H)$, retinoic acid $(R A)$, cyclohexamide $(C H X)$, or no treatment (NORX). $10 \mu \mathrm{g}$ of RNA was resolved on a $1 \%$ agarose gel, transferred to nitrocellulose and hybridized with a ${ }^{32} \mathrm{P}$ random prime labeled fragment of the human TSP 1 cDNA (23). Integrity of the RNA was evaluated by ethidium-bromide staining as shown. Treatment of SMH-KCNR cells with retinoic acid resulted in a rapid $(4 \mathrm{~h})$ induction of the TSP 1 transcript, which was maximal at $24 \mathrm{~h}$ of treatment and superinducible in the presence of cyclohexamide. 


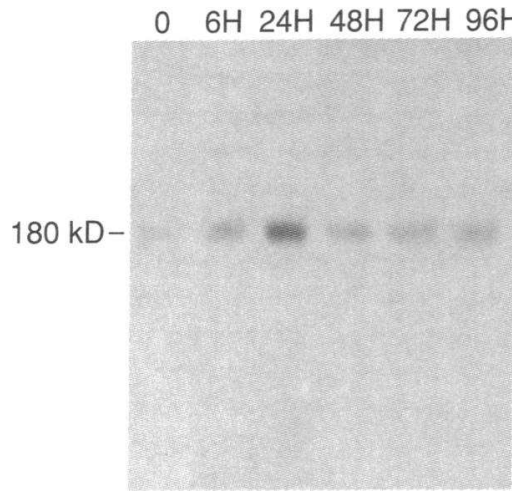

duced $(6 \mathrm{~h})$ after retinoic acid treatment. The induction of TSP reaches a maximum at $24 \mathrm{~h}$ and then remains constant up to $4 \mathrm{~d}$ of treatment. TSP migrates at $180 \mathrm{kD}$.

noic acid in the presence of the protein synthesis inhibitor cycloheximide resulted in a superinduction of TSP 1 transcript. This suggests that no intervening protein synthesis is needed for the induction of TSP 1 transcript by retinoic acid, and therefore TSP 1 is a primary or immediate early response to retinoic acid (27). TSP 2 expression was not detected in untreated cells or at any time point during retinoic acid treatment (data not shown). Quantitative immunoprecipitation with anti-TSP antibody confirmed the Northern blot findings. As early as $6 \mathrm{~h}$ after retinoic acid treatment, an increase in TSP protein was detected in the medium. After peak induction at $24 \mathrm{~h}$ there was a decline, but elevated levels could still be detected as long as 4 $\mathrm{d}$ after induction (Fig. 2). Untreated cells or cells treated with ethanol only showed an extremely low endogenous level of TSP production, without any evidence of induction. Immunoprecipitations from the cell layer gave results identical to those from the medium (data not shown). Immunoperoxidase staining with anti-TSP monoclonal antibody was consistent with the above findings, as immunoreactive TSP was detectable within $24 \mathrm{~h}$ of retinoic acid treatment, and intense staining was evident by $48 \mathrm{~h}$ (data not shown).

The expression of TSP at the onset of neural cell differentiation suggested that TSP may participate in the changes in cell phenotype, which are the appearance of neuritic processes, axons, and dendrites. To assess the contribution of TSP to these early retinoic acid-induced events, anti-TSP monoclonal antibody A 4.1 was used to block TSP function during differentiation. Monoclonal antibody A 4.1 (23) was adsorbed to tissue culture plastic and cells plated and induced with retinoic acid. In these experiments, the cells failed to attach to the tissue culture dishes (data not shown), probably because of an inhibition of TSP-mediated cell attachment. Therefore, in the subsequent set of experiments, the A 4.1 antibody was added with retinoic acid after the cells had been allowed to attach. This resulted in a dramatic inhibition of neurite outgrowth for up to $48 \mathrm{~h}$ after retinoic acid treatment (Fig. 3). This occurred without an observable effect on cell attachment. These findings were quantitated for each treatment group with respect to mean neurite length (Fig. 4) and the total number of cells with
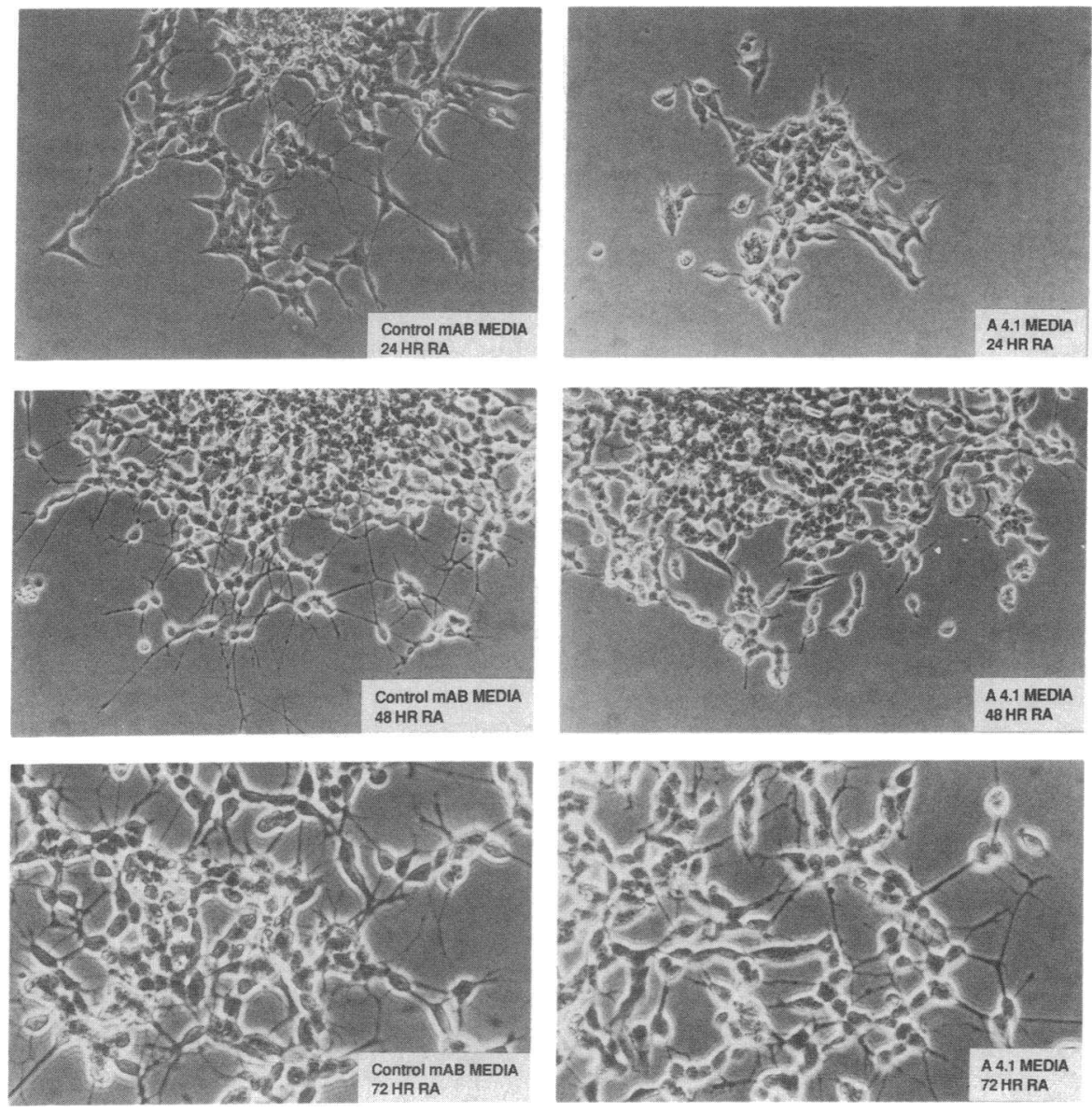

Figure 3. Monoclonal antibody inhibition assay. Cells were plated $24 \mathrm{~h}$ before treatment in serum-free medium to remove any serum source of TSP. Retinoic acid was added to a final concentration of $5 \mu \mathrm{M}$ and anti-TSP or irrelevant mouse monoclonal antibodies were added concomitantly at a concentration of $50 \mu \mathrm{g} / \mathrm{ml}$. Medium was changed every other day. Experiments were performed in duplicate and cells were photographed using a Leitz inverted microscope with a $35-\mathrm{mm}$ camera. 


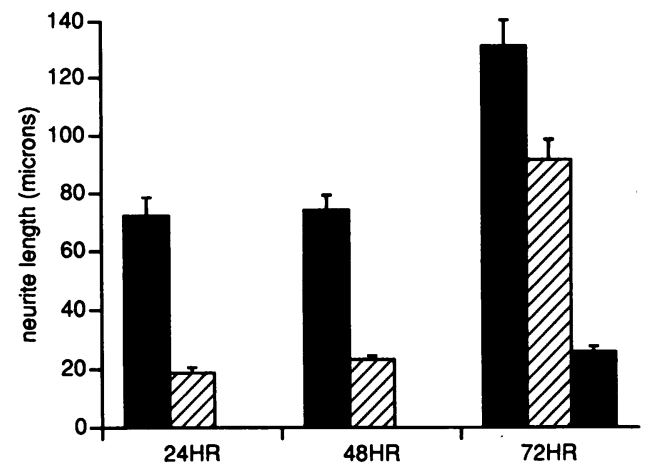

Figure 4. Quantification of neurite outgrowth. SMH-KCNR cells treated with retinoic acid in the presence of control monoclonal antibody (M45Q) $\mathrm{n}$, anti-TSP monoclonal antibody (A 4.1) ) or both anti-TSP and antilaminin monoclonal antibodies (A004) . Treatment with anti-TSP antibody inhibited differentiation for $48 \mathrm{~h}$, but by $72 \mathrm{~h}$, the cells were able to overcome the effects of anti-TSP antibody.

neurites greater than two cell bodies in length (Table I). $88 \%$ of control treated cells formed neurites within $24 \mathrm{~h}$ of retinoic acid treatment with a mean neurite length of $72.6 \pm 6.5 \mu \mathrm{M}$ (mean \pm SEM). By $48 \mathrm{~h}, 94 \%$ of the retinoic acid-treated cells had neurites measuring $74 \pm 5.3 \mu \mathrm{M}$ (mean \pm SEM) in length, and by $72 \mathrm{~h}$, the neurites showed marked extension over $131.5 \pm 8.6 \mu \mathrm{M}($ mean \pm SEM $)$ in length in $96 \%$ of the cells. This pattern was in contrast to groups treated with anti-TSP antibodies. For the first $48 \mathrm{~h},<30 \%$ of cells extended neurites and the mean neurite length was $<25 \mu \mathrm{M}(P<.001)$. By $72 \mathrm{~h}$, the cells overcame this inhibition with $74 \%$ of cells forming neurites with a mean length of $92 \pm 6.7 \mu \mathrm{M}$. This suggested that TSP was primarily involved in the initial burst of neurite outgrowth, and that other neurite outgrowth promoting factors that were not inhibitable by anti-TSP antibodies became dominant by $72 \mathrm{~h}$.

To address this possibility, we investigated the role of laminin as it has been previously shown to have potent neurite outgrowth promoting activities (28). Quantitative immunoprecipitation using a polyclonal antilaminin antibody revealed a marked induction of laminin B 1 and B 2 chains after retinoic acid treatment (Fig. 5). The B 1 chain $(210 \mathrm{kD})$ and B 2 chain $(200 \mathrm{kD})$ are not separable by $\operatorname{SDS}-\operatorname{PAGE}(29,30)$ and comigrate as the upper band in Fig. 5. The faster migrating lower band represents entactin ( $150 \mathrm{kD})$, which has been shown previously to coprecipitate with laminin $(31,32)$. Unlike TSP 1 , which is maximally produced at $24 \mathrm{~h}$, laminin production

Table I. Percentage of Cells with Neurites Greater Than Two Cell Bodies in Length

\begin{tabular}{lc}
\hline Treatment group & $\begin{array}{c}\text { Percentage with neurites } \\
\text { greater than two } \\
\text { cell bodies }\end{array}$ \\
\hline 24 h control & 88 \\
48 h control & 94 \\
72 h control & 96 \\
24 h anti-TSP & 18 \\
48 h anti-TSP & 28 \\
72 h anti-TSP & 74 \\
72 h anti-TSP/laminin & 22 \\
\hline
\end{tabular}

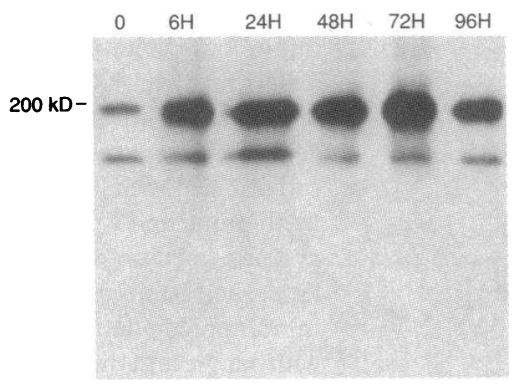

Figure 5. Quantitative immunoprecipitation of laminin from SMHKCNR cells treated with retinoic acid. After metabolic labeling the medium was immunoprecipitated with rabbit anti-human laminin antibody (25). Untreated the SMHKCNR cells made a small amount of B 1 and B 2 laminin, but this was increased after retinoic acid treatment and reached a maximum after $72 \mathrm{~h}$ of treatment. B 1 and B 2 comigrate at $200 \mathrm{kD}$. The lower band is entactin $(150 \mathrm{kD})$, which coprecipitates with laminin.

reached its maximum expression at $72 \mathrm{~h}$ and like TSP, maintained a steady-state production out to $4 \mathrm{~d}$. Scanning densitometry demonstrated that the laminin level at $72 \mathrm{~h}$ is 32 times more intense than at $0 \mathrm{~h} ; 2.5$ times more intense than at $6 \mathrm{~h}$; and six times more intense than at $4 \mathrm{~d}$. Untreated cells or cells treated with carrier alone had a low endogenous production of laminin. To determine whether laminin was providing the substrate upon which the cells were able to overcome the early inhibition of the anti-TSP antibody, the cells were treated with monoclonal antibodies directed against TSP and the laminin B 1 chain. The antibody against the laminin B 1 chain has been shown previously to block partially the neurite-promoting activity of laminin (24). At $60 \mathrm{~h}$ after RA induction and incubation with anti-TSP antibody only, cells were exposed additionally to a cocktail containing both anti-TSP and antilaminin monoclonal antibodies. Unlike the initial anti-TSP monoclonal antibody inhibition assay, cells treated with both anti-TSP and anti-laminin B1 antibodies were inhibited from undergoing normal morphological differentiation for up to $72 \mathrm{~h}$ after retinoic acid induction (Fig. 6). Quantitative assessments of neurite length revealed that only $22 \%$ of treated cells had formed neurites and the neurite length was only $25.7 \pm 2.2 \mu \mathrm{M}$ (mean \pm SEM, $P<0.001$ ) in length. Cell viability was not affected by any of the antibodies, as determined by trypan blue staining. These findings suggest that monoclonal antibodies to both TSP and laminin are potent inhibitors of retinoic acid-induced morphological differentiation: many fewer cells extend neurites, and the neurites that do appear are much shorter.

To determine whether the $\mathrm{NH}_{2}$-terminal heparin-binding domain of TSP or the RGD sequence in its carboxy-terminal domain contributed to neurite outgrowth, competitive inhibition studies were carried out. Cells were treated with retinoic acid in the presence of various concentrations of heparin (10$500 \mu \mathrm{g} / \mathrm{ml}$ ) or a GRGDS peptide ( 100 or $500 \mu \mathrm{g} / \mathrm{ml}$ ). Neither heparin nor the GRGDS peptide was able to inhibit retinoic acid induced neurite outgrowth (data not shown), suggesting that these two potential cell attachment sites in TSP do not play a role in neurite outgrowth.

\section{Discussion}

Previous investigators have established a role for retinoic acid in the induction of differentiation of neuroblastoma cells in vitro (18), and clinical trials are on going to investigate the role of retinoic acid in relapsed neuroblastoma $(33,34)$. Although a 

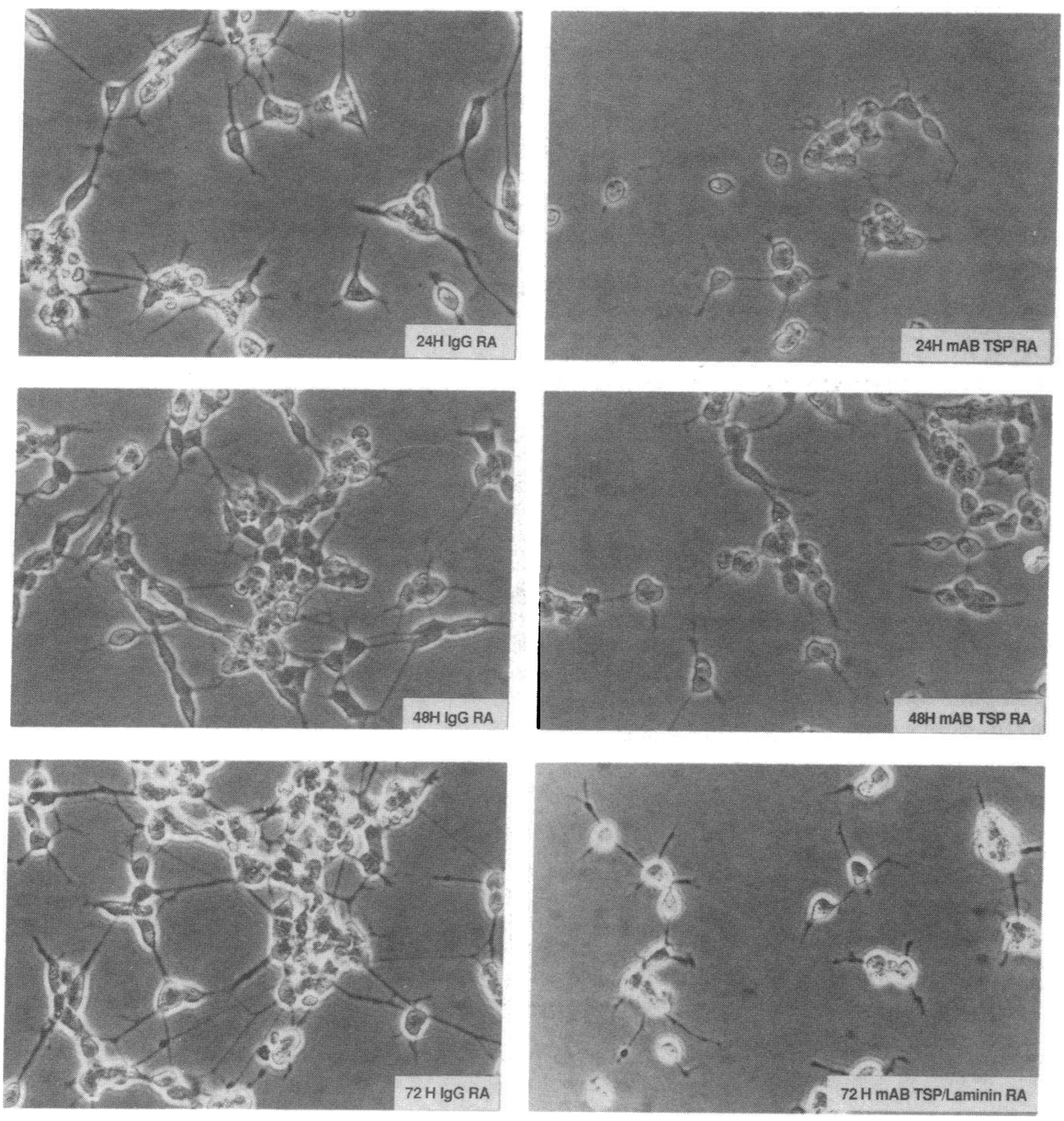

Figure 6. Monoclonal antibody inhibition assay using both anti-TSP and antilaminin antibodies. Cells were plated as described and treated with control monoclonal antibody in the presence of retinoic acid or anti-TSP antibody for $60 \mathrm{~h}$, at which time antilaminin antibody was also added. The addition of both anti-TSP and antilaminin antibody resulted in complete inhibition of differentiation.

great deal has been learned about the influence of retinoic acid on the expression of homeobox proteins (35) and the crucial role that retinoids appear to play in embryogenesis (6-8), little is known about the induction of immediate early genes in the differentiation process. Such genes represent the initial genetic response of a cell to agonist and are thought to initiate alterations in subsequent gene expression and cell behavior. Indeed, the cloning and characterization of the retinoic acid induced immediate early gene product, ERA-1 as being homologous to the homeobox protein Hox $1.6(36,37)$, substantiates the importance of immediate early response genes in cell commitment and differentiation. Later studies have shown that retinoic acid is able to induce differential expression of the HOX gene complex in embryonic cell cultures (38-40), further emphasizing the importance of retinoic acid in cell differentiation. It is thus no surprise that retinoic acid has recently been identified as the endogenous morphogen responsible for chicken limb bud development and a potential regulator of central nervous system development (41-43). The best studied effects of retinoic acid on cell differentiation have been carried out in F9 embryonal carcinoma cells. When exposed to retinoic acid, these cells differentiate to primitive endoderm and in the concomitant presence of cAMP differentiation proceeds towards parietal endoderm. This sequence of differentiation events is accompanied by the stimulation of synthesis of a number of extracellular matrix components including laminin, type IV collagen, entactin, and SPARC, which presumably contribute to the differentiated phenotype $(31,32,44-46)$. Other em- bryonal carcinoma cell lines like P19 and neuroblastoma lines respond to retinoic acid by displaying a differentiated neuronal phenotype characterized by neuritic processes, microtubule bundling, and cessation of cell division $(47,48)$. We find that one of the genes induced by retinoic acid during differentiation of the neuroblastoma cell line SMH-KCNR is the cell surface/ matrix protein thrombospondin. TSP is induced as an immediate early response to retinoic acid in that the induction of its transcript is not susceptible to inhibition by inhibitors of protein synthesis, suggesting that TSP may play a role early on in neuronal differentiation. This is confirmed by the finding that the addition of anti-TSP 1 monoclonal antibodies to retinoic acid induced KCNR cells results in a dramatic inhibition in neurite outgrowth over the first $48 \mathrm{~h}$. Thus, the induction of TSP by retinoic acid appears to be important to the early phase of neurite outgrowth. After $48 \mathrm{~h}$, the neurite outgrowth promoting function of TSP is superseded by laminin, a potent stimulator of neurite outgrowth that is maximally induced by retinoic acid at $72 \mathrm{~h}$. This helps explain the inability of antiTSP monoclonal antibody to effectively inhibit neurite outgrowth at later times in differentiation (post-48 h). Consistent with this is the finding that a combination of anti-TSP and anti-laminin antibodies will inhibit neurite outgrowth at later time periods. Taken together, the data implies an absolute requirement for TSP in the early phases of neurite outgrowth, and a requirement of both TSP and laminin in the later stages. Experiments done to reveal which region of the TSP molecule was responsible for the neurite outgrowth promoting activity 
showed that neither the $\mathrm{NH}_{2}$-terminal heparin binding domain or the RGD sequence at the $\mathrm{COOH}$ terminus was involved. These findings are in complete agreement with previously published reports showing these sequences do not play a role in the attachment of neuronal and other cell types $(16,48,49)$. For endothelial cells, TSP attachment appears to be dependent on the RGD sequence, however, in neurite outgrowth blocking these sequences do not result in inhibition indicating that additional sequences are involved in mediating neurite outgrowth.

The induction of TSP by retinoic acid as an immediate early response, that is, one not requiring intervening protein synthesis suggests that retinoic acid must directly influence TSP gene transcription. One cannot totally discount a posttranscriptional or translational effect of retinoic acid on TSP synthesis, but this is highly unlikely, since no such effects of retinoic acid have been described. On the contrary, it is now quite evident that the mechanism of action of retinoic acid involves the modulation of gene transcription by two families of retinoic acid receptors, the RARs $(50,51)$ and the RXRs (52). Surprisingly, the cis-acting recognition sequences for this family of nuclear transcriptional factors is absent from the TSP promoter (53). Given this, it is clearly important that future work establish ihe exact mechanism of retinoic acid-induced TSP induction, a process critical to the expression of the differentiated neuronal phenotype. In addition, our work raises the possibility that TSP expression may be used as a marker of neuroblastoma differentiation, and hence, potentially as a prognostic marker for this disease.

\section{Acknowledgments}

This work was supported by grants from the National Institutes of Health (NIH)-National Cancer Institute (CA-01599-01) to V. P. Castle and NIH (HD-23867) to V. M. Dixit and S. O'Shea. V. M. Dixit is an Established Investigator of the American Heart Association.

\section{References}

1. Evans A. E., G. J. D'Angio, and J. Randolph. 1971. A proposed staging for children with neuroblastoma: children's cancer study group A. Cancer (Phila.) 27:374-378.

2. Sidell, N. 1982. Retinoic acid induced growth inhibition and morphologic differentiation of human neuroblastoma cells in vitro. J. Natl. Cancer Inst. (Bethesda). 68:589-593.

3. Huang, F. L., D. R. Roop, and L. M. DeLuca. 1986. Vitamin A deficiency and keratin biosynthesis in cultured hamster trachea. In Vitro Cell \& Dev. Biol. 22:223-230.

4. McDowell, E. M., T. Ben, C. Newkirk, S. Chang, and L. M. DeLuca. 1987. Differentiation of tracheal mucociliary epithelium in primary cell culture recapitulates normal fetal development and regeneration following injury in hamsters. Am. J. Pathol. 129:511-522.

5. Hogan, B. L., A. Taylor, and E. Adamson. 1981. Cell interactions modulate embryonal carcinoma cell differentiation into parietal or visceral endoderm. $\mathrm{Na}$ ture (Lond.). 292:235-237.

6. Thompson, J. N., J. McC. Howell, and G. A. J. Pitt. 1969. The biological activity of retinoic acid in the domestic fowl and the effects of vitamin A deficiency on the chick embryo. Br. J. Nutr. 23:471-490.

7. Wedden, S., C. Thaller, and G. Eichele. 1990. Targeted slow-release of retinoids into chick embryos. Methods Enzymol. 190B:201-209.

8. Noji, S., T. Nohno, E. Koyama, K. Muto, K. Ohyama, Y. Aoki, K. Tamura, K. Ohsugi, H. Ide, S. Taniguchi, and T. Saito. 1991. Retinoic acid induces polarizing activity but is unlikely to be a morphogen in the chick limb bud. Nature (Lond.). 350:83-86.

9. Ross, S. A., R. A. Ahrens, and L. M. DeLuca. 1991. Retinoic acid enhances attachment of F9 teratocarcinoma cells to laminin. Proc. Am. Assoc. Cancer Res. 32:128. (Abstr.)

10. De Luca, L. M., S. Adamo, and S. Kato. 1990. Retinoids and the control of cell adhesion. Methods Enzymol. 190:81-91.
11. Wang, S. Y., and L. J. Gudas. 1988. Protein synthesis inhibitors prevent the induction of laminin B1, collagen IV (alpha 1) and other differentiation-specific mRNAs by retinoic acid in F9 teratocarcinoma cells. J. Cell. Physiol. 136:305-311.

12. Dixit, V. M., G. A. Grant, S. A., Santoro, and W. A. Frazier. 1984. Isolation and characterization of a heparin-binding domain from the amino terminus of platelet thrombospondin. J. Biol. Chem. 259:10100-10105.

13. Lawler, J., L. H. Derrick, J. E. Connolly, J. H. Chen, and F. C. Chao. 1985. The structure of human platelet thrombospondin. J. Biol. Chem. 260:37623772 .

14. Bornstein, P., K. O'Rourke, K. Wikstrom, F. W. Wolf, R. Katz, P. Li, and V. M. Dixit. 1991. A second expressed thrombospondin gene (THBS 2) exists in the mouse genome. J. Biol. Chem. 266:12821-12824.

15. O'Shea, K. S., and V. M. Dixit. 1988. Unique distribution of the extracellular matrix component thrombospondin in the developing mouse embryo. $J$. Cell Biol. 107:2737-2748.

16. O'Shea, K. S., L.-H. J. Liu, and V. M. Dixit. 1991. Thrombospondin and a $140 \mathrm{kd}$ fragment promote adhesion and neurite outgrowth from embryonic central and peripheral neurons and from PC 12 cells. Neuron. 7:231-237.

17. Neugebauer, K. M., C. J. Emmett, K. A. Venstrom, and L. F. Reichardt. 1991. Vitronectin and thrombospondin promote retinal neurite outgrowth: developmental regulation and role of integrins. Neuron. 6:345-358.

18. Theile, C. J., C. P. Reynolds, and M. A. Israel. 1985. Decreased expression of $\mathrm{N}$-myc precedes retinoic acid-induced morphological differentiation of human neuroblastoma. Nature (Lond.). 31:404-406.

19. Dixit, V. M., R. M. Marks, V. Sarma, and E. V. Prochownik. 1989. The anti-mitogen action of tumor necrosis factor is associated with increased AP-1/cjun protooncogene transcription. J. Biol. Chem. 264:16905-16910.

20. Dixit, V. M., S. W. Hennessy, G. A. Grant, P. Rotwein, and W. Frazier. 1986. Characterization of a cDNA encoding the heparin and collagen binding domains of human thrombospondin. Proc. Natl. Sci. USA. 83:5449-5453.

21. Varani, J., V. M. Dixit, S. E. G. Fligiel, P. E. McKeever, and T. E. Carey. 1986. Thrombospondin-induced attachment and spreading of human squamous carcinoma cells. Exp. Cell Res. 167:376-390.

22. Castle, V., J. Varani, S. Fligiel, E. V. Prochownik, and V. Dixit. 1991. Antisense-mediated reduction in thrombospondin reverses the malignant phenotype of a human squamous carcinoma. J. Clin. Invest. 87:1883-1888.

23. Prater, C. A., J. Plotkin, D. Jaye, and W. A. Frazier. 1991. The properdinlike type 1 repeats of human thrombospondin contain a cell attachment site. $J$. Cell Biol. 112:1031-1040.

24. Engvall, E., G. E. Davis, K. Dickerson, E. Ruoslahti, S. Varon, and M. Manthorpe. 1986. Mapping of domains in human laminin using monoclonal antibodies: localization of the neurite-promoting site. J. Cell Biol. 103:24572465 .

25. Biondi, A., T. H. Rossing, J. Bennett, and R. F. Todd III. 1984. Surface membrane heterogeneity among human mononuclear phagocytes. J. Immunol. 132:1237-1243.

26. Almendral, J. M., D. Sommer, H. MacDonald-Bravo, J. Burkhardt, J. Perera, and R. Bravo. 1988. Complexity of the early genetic response to growth factors in mouse fibroblasts. Mol. Cell. Biol. 8:2140-2148.

27. Toskos, M., S. Scarpa, R. A. Ross, and T. J. Triche. 1987. Differentiation of human neuroblastoma recapitulates neural crest development, study of morphology, neurotransmitters, enzymes and extracellular matrix proteins. Am. J. Pathol. 128(3):484-96.

28. Boot-Handford, R. P., M. Kurkinen, and D. J. Prockop. 1987. Steadystate levels of mRNAs coding for the type IV collagen and laminin polypeptide chains of basement membranes exhibit marked tissue-specific stoichiometric variations in the rat. J. Biol. Chem. 262:12475-12478.

29. Kleinman, H. K., I. Ebihara, P. D. Killen, M. Sasaki, F. B. Cannon, Y. Yamada, and G. R. Martin. 1987. Genes for basement membrane proteins are coordinately expressed in differentiating F9 cells but not normal adult murine tissues. Dev. Biol. 122:373-378.

30. Carlin, B. E., M. E. Durkin, B. Bender, R. Jaffe, and A. E. Chung. 1983. Synthesis of laminin and entactin by F9 cells induced with retinoic acid and dibutyryl cyclic AMP. J. Biol. Chem. 258:7729-7737.

31. Cooper, A. R., A. Taylor, and B. L. Hogan. 1983. Changes in the rate of laminin and entactin synthesis in F9 embryonal carcinoma cells treated with retinoic acid and cyclic AMP. J. Biol. Chem. 99:510-516.

32. Reynolds, C. P., D. J. Kane, P. A. Einhorn, K. K. Matthay, V. L. Crouse, J. R. Wilbur, S. B. Shurin, and R. C. Seeger. 1991. Response of neuroblastoma to retinoic acid in vitro and in vivo. Prog. Clin. Biol. Res. 366:203-211.

33. Children's Cancer Study Group Protocol 8607: Evaluation of 13-Cis-Retinoic Acid as Maintenance Therapy for Neuroblastoma after Bone Marrow Transplantation.

34. Lewis, J., and P. Martin. 1989. Vertebrate development. Limbs: a pattern emerges. Nature (Lond.). 342:734-735.

35. LaRosa, G. J., and L. J. Gudas. 1988. An early effect of retinoic acid: cloning of an mRNA (ERA-1) exhibiting rapid and protein synthesis-independent induction during teratocarcinoma stem cell differentiation. Proc. Natl. Acad. Sci. USA. 85:329-333. 
36. LaRosa, G. J., and L. J. Gudas. 1988. Early retinoic acid induced F9 teratocarcinoma stem cell gene ERA-1: alternate splicing creates transcripts for a homeobox-containing protein and one lacking the homeobox. Mol. Cell. Biol. 8:3906-3917.

37. Simeone, A., D. Acampora, L. Arcioni, P. W. Andrews, E. Boncinelli, and F. Mavilio. 1990. Sequential activation of HOX 2 homeobox genes by retinoic acid in human embryonal carcinoma cells. Nature (Lond.). 346:763-766.

38. Papalopulu, N., P. Hunt, D. Wilkinson, A. Graham, and R. Krumlauf. 1990. Hox-2 homeobox genes and retinoic acid: potential roles in patterning the vertebrate nervous system. In Advances in Neural Regeneration Research. Alan R. Liss Inc., New York. 291-307.

39. Simeone, A., D. Acampora, V. Nigro, A. Faiella, M. D'Esposito, A. Stornaiuolo, F. Mavilio, and E. Boncinelli. 1991. Differential regulation by retinoic acid of homeobox genes of the four HOX loci in human embryonal carcinoma cells. Mech. Dev. 33:215-228.

40. Maden, M., and C. Tickle. 1991. Retinoic acid and vertebrate development. Semin. Dev. Biol. 2:151:228.

41. Wagner, M., C. Thaller, T. M. Jessell, and G. Eichele. 1990. Polarizing activity and retinoic synthesis in the floor plate of the neural tube. Nature (Lond.). 345:819-822.

42. Sharpe, C. R. 1991. Retinoic acid can mimic endogenous signals involved in transformation of the xenopus nervous system. Neuron. 7:239-247.

43. Marotti, K. R., G. D. Brown, and S. Strickland. 1985. Two-stage hormonal control of type IV collagen mRNA levels during differentiation of F9 teratocarcinoma cells. Dev. Biol. 108:26-31.

44. Wang, S. Y., and G. L. Gudas. 1983. Isolation of cDNA clones specific for collagen IV and laminin from mouse teratocarcinoma cells. Proc. Natl. Acad. Sci. USA. 80:5880-5884.

45. Mason, I. J., A. Taylor, J. G. Williams, H. Sage, and B. L. Hogan. 1986. Evidence from molecular cloning that SPARC, a major product of mouse embryo parietal endoderm, is related to an endothelial cell 'culture shock' glycoprotein of Mr 43,000. EMBO (Eur. Mol. Biol. Organ.) J. 5:1465-1472.

46. Dinsmore, J. H., and F. Solomon. 1991. Inhibition of MAP 2 expression affects both morphological and cell division phenotypes of neuronal differentiation. Cell. 64:817-826.

47. C. L. Cepko. 1989. Immortalization of neural cells via retrovirus-mediated oncogene transduction. Annu. Rev. Neurosci. 12:47-65.

48. Roberts, D., J. A. Sherwood, and V. Ginsburg. 1987. Platelet thrombospondin mediates attachment and spreading of human melanoma cells. J. Cell Biol. 104:131-139.

49. Varani, J., B. J. Nickoloff, B. L. Riser, R. S. Mitra, K. O'Rourke, and V. M. Dixit. 1988. Thrombospondin-induced adhesion of human keratinocytes. J. Clin. Invest. 81:1537-1544.

50. Petkovich, M., N. J. Brand, A. Krust, and P. Chambon. 1987. A human retinoic acid receptor which belongs to the family of nuclear receptors. Nature (Lond.). 330:444-450.

51. Giguere, V., E. S. Ong, P. Segui, and R. M. Evans. 1987. Identification of a receptor for the morphogen retinoic acid. Nature (Lond.). 330:624-629.

52. Mangelsdorf, D. J., E. S. Ong, J. A. Dyck, and R. M. Evans. 1990. Nuclear receptor that identifies a novel retinoic acid response pathway. Nature (Lond.). 345:224-229.

53. De Luca, L. M. 1991. Retinoids and their receptors in differentiation, embryogenesis and neoplasia. FASEB (Fed. Am. Soc. Exp. Biol.) J. 5:2924-2933. 